\title{
Learning to Teach Basic School Mathematics: Lessons from a Pedagogical Course
}

\author{
Wilmot, E. M. ${ }^{1}$
}

\begin{abstract}
This is an empirical study designed to investigate the ideas pre-service elementary teachers bring into a mathematics pedagogy course, how these ideas change over the course of the semester and find out what the sources of the changes are. The study involved ten pre-service elementary teachers in one pedagogical course in mathematics offered at a Midwestern University in the United States of America in 2003. Analyses of data revealed that on the whole very small things changed. Specifically, while some participants still maintained static and more prescriptive views of mathematics and the teaching of mathematics, others showed slight movement toward socio-constructive ideas of teaching. The sources of these changes ranged from more techniques from their field placements to interaction with peers in course discussions. Relying on available literature on ways of challenging the wrong views pre-services teachers bring to their coursework from the long years in school as students, recommendations have been made about the need to consider using multimedia systems to help pre-service teachers learn to teach in a reflective and critical manner.
\end{abstract}

Keywords pre-service teachers, mathematics pedagogy course, views of nature of mathematics, views of teaching of mathematics

\section{Background to the study}

Available literature indicates that pre-service teachers enter formal teacher education programs with ideas and thinking about subject matter, about teaching and learning and about schools which they have formed from their long experience as students. The effect of this "apprenticeship of observation" (Lortie, 1975) is so strong that pre-service teachers could have a tendency to dismiss alternative ideas about the teaching of mathematics provided in teacher education as theoretical and unrealistic (Lampert \& Ball, 1990). In situations where they do not completely dismiss such alternative ideas, literature is replete with the fact that the initial ideas formed from their long experience as students influence what pre-service teachers in general learn from their courses and field experiences (Bullough, 1997; Anderson \& Bird, 1992; Calderhead, 1991; Ball, 1988a \& 1988b; Fieman-Nemser, \& Buchmann, 1986).

In addition, mathematics teacher education has been noted to be fraught with two main tensions that can negatively affect pre-service elementary teachers' attempt at learning to

${ }^{1}$ Dr. E. M. Wilmot lectures at the Department of Science and Mathematics Education, University of Cape Coast, Ghana. 
teach mathematics for understanding (Ball, 1990). The first of these tensions is preservice elementary teachers' weak understanding of the subject matter of mathematics; something that could prove a substantial obstacle to their attempt at learning to teach mathematics for understanding. The second is the duration of the methods courses; within a short period of time, only some things change. Consequently, though methods courses may have an impact, it is unclear how this impact can help redirect the continuity of preservice teachers' learning to teach mathematics. In fact, research has been found to provide limited support for concluding that there is potential for pedagogical coursework to contribute to teacher effectiveness (Educational Commission of the States (ECS), 2003).

The aforementioned problems do not in any way mean that pedagogical courses in preservice teacher education are ineffective or uncalled for. On the contrary, it is well documented that even with strong subject matter background, teachers without subject matter pedagogical preparation could not engage their students in deep thinking about the subject matter of mathematics but only teach the way they were taught (DarlingHammond, 1999 \& 1991; Fergusson \& Womack, 1993; Grossman, 1989; Shulman, 1987). For instance, in a three-year study, Ferguson and Womack (1993) found that course work in teacher education better predicted teacher effectiveness than measures of content expertise alone. This finding is supported by other studies reviewed by DarlingHammond (1999), which show that students of certified teachers score higher on standardized mathematics test than those of uncertified teachers. Earlier, DarlingHammond (1991) had cited several studies that reveal that teachers admitted to the profession through quick-entry alternative routes had difficulty with pedagogical content knowledge and curriculum development. She also cites several studies supporting the efficacy of subject-specific methods courses for those preparing to teach. The implication of these is that, teachers generally need more than sound subject matter knowledge to be effective in their work.

There is therefore the need to investigate the type of experiences needed to help prospective teachers learn to teach mathematics effectively. One way of doing this is for mathematics teacher preparation to take into account ideas teacher candidates bring with them to teacher education programs, and develop ways of challenging, changing, and extending what they know, believe and care about. Though this is not a simple thing to do, it still needs to be done if teacher education is to be effective (Ball, 1988b).

It is in the light of this that the study reported in this paper was designed to investigate ideas elementary teacher candidates bring with them to a mathematics pedagogy course in their teacher education program and to see how these change based on the experiences they are presented with in the course.

\section{Research Questions}

This paper, reports on a study that examined the ideas about mathematics and the teaching of mathematics which pre-service elementary teachers bring to a pedagogy course in mathematics and how, in their perspective, these ideas changed during the semester. The following research questions guided the study. 
1. What ideas about mathematics and the teaching of mathematics do pre-service teachers bring with them to a pedagogical coursework in mathematics?

2. How do these ideas change, if any through the duration of the coursework?

3. If there is a change, what, in the perspective of the pre-service teachers, is source of this change?

\section{Theoretical Framework}

The design of the study warranted a framework that would aid effective conceptualization of the baseline data. One study that did this type of conceptualization is the Thompson (1984) study. Thompson (1984) reports of a study of three teachers by conceptualizing their attitude towards mathematics, their views about mathematics and beliefs about the teaching of mathematics as well as how these affected the decisions they made in their classrooms. Therefore, to aid initial conceptualizations participants' attitude towards mathematics, views about mathematics and their beliefs about the teaching of mathematics, Thompson (1984)'s ideas are used as framework.

Thompson (1984) conducted case studies to investigate three junior high school mathematics teachers' conceptions of mathematics and mathematics teaching and how these played out in their teaching. The discussion these conceptions reveal differences in the teachers' attitudes towards mathematics, views of mathematics and beliefs about the teaching of mathematics. Thompson (1984)'s conceptualization of these conceptions, discussed in the subsections that follow were the lenses employed in analyzing the data.

\section{Categorization of students' attitude towards mathematics}

In terms of pre-service teachers attitude towards mathematics (i.e. like and dislike statements explicitly made about mathematics), three main categorizations come out Thompson (1984)'s report. These are (1) those who have negative attitude towards mathematics due to unpleasant past experiences. (2) those who have a positive view of mathematics and (3) those who could have mixed reactions towards school mathematics, due to their past experiences.

These negative attitudes come out in expressions like, "I do not enjoy or like mathematics". For instance, in Thompson (1984) cites Jeanne as someone who reports of times in her life when she did not enjoy mathematics. The positive attitudes, on the other hand, come out in expressions like, "I enjoy or like mathematics". Thompson (1984) also revealed that teachers who may have the same or similar attitudes towards mathematics may attribute their source of their attitudes to different experiences or reasons. For instance, in Thompson (1984), Kay and Lynn are described as teachers who have positive attitudes towards mathematics. However, each person's likeness of the subject was a result of different experiences. Whereas Kay's “enjoyment of mathematics was derived from the many opportunities its study provides to exercise one's inventiveness and reasoning skills" (p. 113) Lynn's likeness of the subject "was derived from the fact that there were right answers that provided immediate feedback on the correctness of her work" (p. 116). 
Learning to Teach Basic School Mathematics: Lessons from a Pedagogical Course

Wilmot, E. M.

The mixed reactions towards school mathematics show in the form of someone showing evidence of times in his life as a student when a particular teacher made him to like or enjoy and other times when the opposite occurred. For instance, in discussing Jeanne's attitude toward mathematics, Thompson (1984) wrote, "she clearly had two unrelated views of mathematics that seemed to be the result of two distinct experiences in her study of the subject. One was a positive view that seemed to have been influenced by a favorable experience with school mathematics. The other was related to an unpleasant experience with college mathematics - specifically with calculus and linear algebra" (p110).

\section{Categorization of students' views of mathematics}

Thompson (1984) discusses four main categorizations of teachers' views of mathematics. First, there are those who would view mathematics as a static body of knowledge. This is the view that mathematical knowledge is a fixed form of knowledge teachers can make accessible to students. For instance, Lynn's view of mathematics inferred from her teaching is said to reflect "a view of mathematics ... consisting of a static collection of facts, methods, and rules necessary for finding answers to specific tasks" (Thompson, 1984, p. 116). Jeanne also holds such a view.

Second, there are those who would view math as a coherent set of logically related topics. This is the view that sees the content of school mathematics as integrated and related. In contrast with the static view, such a view can be termed a dynamic view of mathematics. An example of this view is held by Kay who is described as someone who held a "dynamic view of mathematics" (p.120).

There are also those who see math as an incoherent body of knowledge. This is the view that mathematics consists of unrelated topics that need to be learnt separately.

Finally, there are teachers who may express contradictory views of mathematics. Such teachers may act on occasions as though they see mathematics as coherent and yet on other occasions behave as though mathematics is an incoherent body of knowledge. Thompson (1984) cites Lynn as an example of such teachers (see p.119).

\section{Categorization of students' beliefs about the teaching of mathematics}

Four categories of beliefs of mathematics teaching can be inferred from Thompson (1984)'s description of teaching approaches implemented by the three subjects of his study in their classrooms. He linked these beliefs with the views the teachers held about mathematics.

For instance, mention is made of a belief in process-oriented approaches in the teaching of mathematics. From the report, it can be inferred that such a belief plays out in teaching that emphasize conceptual understanding of the subject and thereby giving students opportunity to reason about mathematics. According to Thompson 91984), Kay is an example of this belief because she believed that "students learn best by doing and reasoning about mathematics on their own [and this view] was consistent with her dynamic view of mathematics" (p. 120). 
There is also the belief held by some teachers that the teaching of mathematics should be prescriptive in approach. To such people it is the responsibility of teachers to "direct and control all classroom activities [and like Jeanne], attempt to present lessons in an orderly and logical sequence, avoiding digressions to discuss students' difficulties and ideas" (Thompson, 1984, p. 120). Teachers with this belief also see mathematics as a static body of knowledge and that explains why they present mathematics as a finished product to students.

Third, there is the belief that mathematics teaching should emphasize the learning of procedures. Lynn is cited as an example of this belief because she believed that "her role in teaching was to demonstrate the procedures that students were to use in performing the tasks in the daily assignments and to allow time for students to work independently on them ... To Lynn, mathematical understanding was tantamount to the students' ability to follow and verbalize the procedures taught to obtain correct answers" (p. 120).

Fourth, there is the belief that the best way to teach mathematics is to emphasize the utilitarian or practical values of the subject. This belief shows up in statements like, "the primary purpose of mathematics is to serve as a tool for the sciences and other fields of human endeavor" (Thompson, 1984, p113).

\section{Procedure}

This study took place during the Fall semester of 2003. Participants of this study comprised ten pre-service elementary teachers who were part of the students in a pedagogical course in mathematics at the Midwestern University in the United States of America.

In this class, students were engaged in class discussions of course readings and presentations of group lessons. The students were also given opportunities for reflective and critical thinking about the teaching of mathematics using an online multimedia system, SLE. The Student Learning Environment (SLE), is a web-based multimedia environment, developed by Lampert and Ball, which enables students to access their (Lampert and Ball) actions as teachers over a period of one year in two elementary school mathematics classrooms-- a third-grade class taught by Ball and a fifth-grade class taught by Lampert. In this pre-service teachers' class discussions during the SLE sessions were organized around three themes; 1) Creating a classroom culture that supports the learning of mathematics, 2) developing mathematical reasoning through problem solving, and 3) Planning and teaching mathematics learning. Pre-service teachers in this class wrote reflections on their readings, as well as the teaching sessions they observed on SLE and were occasionally given tasks (including lesson plans) to perform in class. The course also coincided with their initial field placements in schools where they could observe teachers at work. The opportunity was therefore taken during the semester to provide opportunities for the pre-service teachers not only to implement ideas developed in the course at the placement sites but also to bring experiences from their placement schools for discussion. 
At the beginning of the semester, students in this class were asked to write "a brief philosophy of teaching highlighting their ideas about mathematics and the teaching of mathematics at the elementary school". This was to provide the baseline data about the ideas they brought with them to the class at the beginning of the semester. In the middle of the semester, they were asked to reflect on the philosophy statements and revise them, where necessary, according to whether their initial ideas (attitudes/dispositions) were changing or not, pointing to what might be responsible for changes if any. During the last week of the semester, students were again asked to reflect on the first two philosophy statements and perform a final revision if they considered their ideas to have changed. As they did in the first revision, students were specifically asked to indicate any changes in their ideas, if any, which have occurred since they wrote the first revision, as well as the source of the change where applicable.

Since I was the course instructor, there was the possibility that students were going to write something that differed from their real situations. To avoid this, students were assured that these philosophy statements were not going to be graded but were needed to study how students benefit from the course and to help make future decisions about course content.

\section{Analytic Methods Used}

Initial ideas expressed in pre-service teachers' beginning philosophy statements were categorized first under three main themes generated from the theoretical framework. These are their initial attitude towards mathematics, their initial view of mathematics and their initial view about how to teach mathematics. From these broad categories subthemes were formed to aid further refinement of discussion of specific attitudes and views about mathematics as well as the teaching of mathematics.

Sub-themes formed under pre-service teachers' initial attitude towards mathematics include enjoyment of school mathematics, no enjoyment of mathematics (or the attitude that mathematics is a challenging subject), and mixed reactions consisting of instances when school mathematics was enjoyed and disliked by a particular participant. Under prospective teachers' initial view of mathematics, three sub-themes were formed. These comprised a view of mathematics as a static body of knowledge, a view of mathematics as a coherent set of logically related topics and contradictory view of mathematics as both prescriptive/deterministic as well coherent and logical. Under prospective elementary teachers' initial view of how to teach mathematics four main sub categories were formed. There were those who emphasized the use of hands-on activities, those who emphasized the type of teaching that focused on the utilitarian values of mathematics, those who think that the use of games was the surest pedagogical approach to arouse students' interests in mathematics as well as those who stressed the need to get students to work in groups.

The second and third philosophy statements were then analyzed to see changes that occurred in participants' ideas about the teaching of mathematics or the frequency of non-occurrence of changes in their ideas. As already mentioned, where there were changes in ideas, the sources of such changes were also noted. 


\section{Results and Discussion}

Table 1 below indicates the initial ideas held by the prospective elementary teachers and the number that had the different attitudes. Samples of students' own statements are also provided to provide an idea how these were phrased.

Table 1 Initial attitude of participants toward mathematics

\begin{tabular}{lll}
\hline Attitude toward Math & Number & Student statements \\
\hline Enjoy mathematics & 1 & $\begin{array}{l}\text { My experience in Mathematics has been a positive one. I } \\
\text { think the biggest reason I like math is because my teachers } \\
\text { used activities that we, the students, enjoyed. I like the } \\
\text { challenge of completing a difficult problem and working } \\
\text { through many steps to get the correct answer. }\end{array}$ \\
Do not enjoy mathematics & 7 & $\begin{array}{l}\text { I never enjoyed school mathematics and do not want my } \\
\text { students to have the same distaste as I did }\end{array}$ \\
& $\begin{array}{l}\text { In junior high, my seventh and eighth grade math teacher } \\
\text { was a nightmare. She would give us piles of Math problems } \\
\text { to do each night and not explain anything. I would come } \\
\text { home from school and not accomplish anything. Tears would } \\
\text { flow and I would get myself all worked out. However, my } \\
\text { junior high school Algebra became fun and easier. My } \\
\text { teacher was awesome. They way he explained problem } \\
\text { solving made it easy for me. }\end{array}$ \\
\hline
\end{tabular}

A cursory look at Table 1 reveals that whereas 7 out of the 10 students never enjoyed school mathematics, 2 had mixed reactions and only one student enjoyed the subject in school.

In Table 2 below presents their initial views of mathematics. A cursory look at Table 2 indicates that six of the participants viewed math as a static body of knowledge, four viewed mathematics as incoherent body of knowledge while two consistently the subject as a coherent set of logically related topics. The two who expressed contradictory views of mathematics were also students who also held static views of the subject. 
Learning to Teach Basic School Mathematics: Lessons from a Pedagogical Course

Wilmot, E. M.

Table 2 Participants' initial view of mathematics

\begin{tabular}{|c|c|c|c|}
\hline View of Math & Feature & Sample statements & Number \\
\hline $\begin{array}{l}\text { Static body of } \\
\text { knowledge }\end{array}$ & $\begin{array}{l}\text { Mathematics as fixed } \\
\text { form of knowledge } \\
\text { teachers should make } \\
\text { accessible to students and } \\
\text { it consists of a of facts, } \\
\text { methods, and rules } \\
\text { necessary for finding } \\
\text { answers to specific tasks }\end{array}$ & $\begin{array}{l}\text { For most I think, mathematics is } \\
\text { simply a bunch of numbers and it is } \\
\text { repetitive and meaningless task to } \\
\text { compute the answers. It is the job of } \\
\text { the math teacher to math enjoyable. I } \\
\text { hope I can make children see the } \\
\text { importance of math, and have fun } \\
\text { learning it. }\end{array}$ & 6 \\
\hline $\begin{array}{l}\text { Coherent body of } \\
\text { knowledge }\end{array}$ & $\begin{array}{l}\text { Content of school } \\
\text { mathematics is integrated } \\
\text { and related }\end{array}$ & $\begin{array}{l}\text { I liked math because I could connect } \\
\text { the various topics and did not need to } \\
\text { learn them separately }\end{array}$ & 2 \\
\hline $\begin{array}{l}\text { Incoherent body } \\
\text { of knowledge }\end{array}$ & $\begin{array}{l}\text { Mathematics consists of } \\
\text { unrelated topics that need } \\
\text { to be learnt separately }\end{array}$ & $\begin{array}{l}\text { Not only were the content and } \\
\text { procedural parts of math challenging } \\
\text { for me but also there were many } \\
\text { other side aspects that added to the } \\
\text { discouragement. }\end{array}$ & 4 \\
\hline $\begin{array}{l}\text { Contradictory } \\
\text { views }\end{array}$ & $\begin{array}{l}\text { May see mathematics as } \\
\text { coherent and incoherent } \\
\text { body of knowledge on } \\
\text { different occasions }\end{array}$ & $\begin{array}{l}\text { I feel teachers should help students } \\
\text { connect math ideas to make it easier } \\
\text { to learn }\end{array}$ & 2 \\
\hline
\end{tabular}

In terms of beliefs in the way mathematics needs to be taught, not all of the categories discussed In Table 3 below, the initial views of participants of the teaching of mathematics. From Table 3, it would be seen that of the five participants who held beliefs in process-oriented approaches of teaching mathematics, two said they believe in getting students to work in groups and three emphasized the use of hands-on activities. In addition, three of these five believed that it is the teacher's job to guide students' discussions and group activities to save time, a prescriptive view of teaching.

One student believed in procedural approaches to teaching mathematics while three think that emphasizing the practical applications of the subjects is the best way to make mathematics interesting to students. Finally, one student emphasized the use of games to arouse students' interests. This belief was not a direct categorization from Thompson (1984) but was mentioned by one of the participants of the study. 
Table 3 Participants' initial view of how to teach mathematics

\begin{tabular}{|c|c|c|c|}
\hline $\begin{array}{l}\text { View of Math } \\
\text { teaching }\end{array}$ & Features & Sample statements & Number \\
\hline $\begin{array}{l}\text { Emphasis on } \\
\text { process-oriented } \\
\text { approaches in the } \\
\text { teaching of } \\
\text { mathematics }\end{array}$ & $\begin{array}{l}\text { Giving students opportunity to reason } \\
\text { about mathematics and thereby } \\
\text { emphasize conceptual understanding of } \\
\text { the subject. May play out in the form of } \\
\text { giving students hands-on activities that } \\
\text { help them to develop their learning. } \\
\text { Inquiry approaches could also be } \\
\text { adopted. }\end{array}$ & $\begin{array}{l}\text { Instead of giving } \\
\text { students formulas to } \\
\text { use, I think } \\
\text { emphasizing deep } \\
\text { understanding of } \\
\text { mathematics is better. }\end{array}$ & 5 \\
\hline $\begin{array}{l}\text { Prescriptive in } \\
\text { approach }\end{array}$ & $\begin{array}{l}\text { It is the responsibility of teachers to } \\
\text { direct and control all classroom } \\
\text { activities and present lessons in orderly } \\
\text { and logical sequence. }\end{array}$ & $\begin{array}{l}\text { I have found that it is } \\
\text { not good to teach using } \\
\text { the same techniques. } \\
\text { Teachers should vary } \\
\text { their teaching styles } \\
\text { give students more fun } \\
\text { with mathematics. }\end{array}$ & 1 \\
\hline $\begin{array}{l}\text { Procedural } \\
\text { approach }\end{array}$ & $\begin{array}{l}\text { Demonstration of procedures that } \\
\text { needed in performing mathematical } \\
\text { tasks. }\end{array}$ & $\begin{array}{l}\text { I really enjoyed } \\
\text { counting tool taught us } \\
\text { where you use your } \\
\text { nose and fingers to } \\
\text { solve addition } \\
\text { problems. It's a great } \\
\text { tool for basic } \\
\text { mathematics. }\end{array}$ & 3 \\
\hline $\begin{array}{l}\text { Emphasis on } \\
\text { utilitarian or } \\
\text { practical values }\end{array}$ & $\begin{array}{l}\text { Emphasis on the uses or applications of } \\
\text { mathematics. }\end{array}$ & $\begin{array}{l}\text { Teachers need to let } \\
\text { students see the } \\
\text { application of the } \\
\text { mathematics they are } \\
\text { learning. }\end{array}$ & 3 \\
\hline Using games & $\begin{array}{l}\text { Emphasis on the use of mathematical } \\
\text { games to aid students' learning of the } \\
\text { content. }\end{array}$ & $\begin{array}{l}\text { Using games in } \\
\text { teaching mathematics } \\
\text { can make it more } \\
\text { exciting. }\end{array}$ & 1 \\
\hline
\end{tabular}

\section{Changes in students' beliefs about teaching \& its source}

Analyses of the revised philosophy statements written by these 10 pre-service teachers showed that by the end of the semester, six of them had moved toward socio-constructive ideas of teaching. One prospective teacher who showed this movement said, "I have learned that the key to making math interesting is to allow children to make meaning for themselves as they work in groups". Of those who showed this change, one attributed it to a combination of field experience and interaction with peers in course discussions, 4 were not explicit about the source (just mentioned "through this course" or "through this semester") and 2 traced the source of the change to emphasis on conceptual understanding in course readings and discussions. 
Three students who initially held static and more prescriptive views of mathematics teaching also showed slight changes in their ideas about teaching of mathematics. They still held the static views but began suggesting emphasis on non-rote techniques. These students indicated that they learnt more techniques from their field placements which they could us in their teaching. As one of them put it, "from my field placement, I realize that it is better for teachers to come prepared with strategies to help students discover the math relations. Some children do not learn well if they are only required to learn formulas and apply them".

One student still believed in emphasizing procedural understanding and did not feel there were any changes in the way she felt mathematics should be taught. This student said, "My ideas for teaching math have not changed in this course. I think teachers should be prepared to provide more demonstrations in class".

\section{Conclusions}

Analyses of data revealed that on the whole very small things changed. Specifically, some students still maintained static and more prescriptive view of mathematics but changed only slightly from an emphasis on rote memorization. Others showed slight movement toward socio-constructive ideas of teaching. At the same time, there were those who still believed in emphasizing procedural understanding.

The sources of these changes ranged from more techniques from their field placements through a combination of field experience and interaction with peers in course discussions, to emphasis on conceptual understanding in course readings and discussions. Altogether, majority of the students (5 out of 10) attributed the change in their views about mathematics teaching to their field placements while three traced it to the course readings and discussions with their peers in course discussions (one attributed the change to both field experience, and interaction with peers in course discussions). Even the only one whose ideas did not change referred to her field experience as the source of consolidation of her ideas.

\section{Implications and Recommendations}

As already mentioned, students referred greatly to the experiences they had in their field placement that semester as the source of changes in their ideas. This finding is consistent with the belief that one of the conditions needed to induce conceptual change in teachers is the provision of "examples of . . . practices, preferably under realistic conditions" (Fieman-Nemser \& Remillard, 1996, p.23). Another source that pre-service teachers pointed to as responsible for changes in their ideas was in the class discussions with their peers.

The implication of this is that pre-service mathematics teachers could have their ideas about teaching effectively challenged (1) by being exposed to good experiences of practice and (2) if they could be exposed to opportunities to engage their own thinking as well as those of their peers in a critical and reflective manner. 
The problem with the traditional field experience is that pre-service teachers are usually attached to particular teachers in their field placements. Apart from the fact that their experiences in this arrangement are never the same, it is unclear whether they get the opportunity to conduct a reflective study of their experiences either individually or together. In addition, there is the possibility of pre-service teachers drawing faulty inferences from this first hand experiences (Buchmann \& Schwille, 1982). As a result, several mathematics educators have drawn attention to the need for intensive practical orientation with an emphasis on critical analysis of actual teaching practices. The argument here is that that neither university-based theoretical study of teaching nor learning to teach through unreflective apprenticeship, either separately or together, are likely to produce a career-long orientation of professional learning (Mousley and Sullivan, 1997; Merseth and Lacey, 1993).

It is therefore recommended that pre-service mathematics teachers be exposed to practical experiences that provide them with the opportunity to learn how to teach in a reflective manner. As Sullivan (2002) puts it, "experiences that present or stimulate practice are important, particularly if participants study or critique those practices" (p. 289). This type of experience can be provided through the use of multimedia systems to present authentic teaching situations (i.e., lessons of actual teachers and children at work in classrooms), which could contain good and bad practices, which pre-service teachers can analyse in a reflective and critical manner.

Multimedia systems can be used to provide a variety of cases (teachers at work in actual classrooms) while in each case multiple representations of the teaching context (e.g. recorded lessons can be presented along with their transcripts and interviews with the teacher about why he/she took certain decisions in class etc.) can be provided to help preservice mathematics teachers construct their own knowledge of what it means to teach mathematics. Also, instead of individual attachment to specific classrooms, multimedia systems can be used as a context to engage socially as they learn to teach by making the practice of experienced teachers available to pre-service teachers for analysis, to stimulate reflection (Merseth, 1994).

The potential of multimedia systems to promote this kind of reflective and critical thinking of pre-service mathematics teachers' emerging teaching practice has also been well documented. One of such cases is discussed in Understanding pre-service teachers emerging practices through their analyses of a multimedia case study of practice, by Masingila and Doerr (2002) in their report of an NSF (National Science Foundation) funded study. According to the authors, they "found that having the multimedia case study as a site to investigate, analyze, and reflect on another teacher's practice supported [these pre-service teachers] in (a) focusing on issues that were meaningful to their own teaching practice, and (b) thinking critically about another teacher's practice which in turn promoted critical thinking about their own practice" (Masingila \& Doerr, 2002, p. 259). Another example is seen in the use of the SLE (Student Learning Environment). According to Putnam and Borko (2000), "students' investigations in this multimedia environment [i.e. the SLE] sometimes pushed their thinking beyond where it was when they started" (p.11 of the online version). 
Learning to Teach Basic School Mathematics: Lessons from a Pedagogical Course

Wilmot, E. M.

Another support for the effectiveness of the use of multimedia systems in pre-service teacher education programmes is provided by Secondary Teacher Education Project (STEP). Of the 18 volunteer pre-service teachers who participated in the study, only two of them continued to use teaching models in which teaching is merely a one-way transmission of information. In addition, according to Derry and the STEP Team (2002), written analyses of the video cases produced by the participating pre-service teacher STEP showed flexible application of pieces of different theories rather than application of coherent theoretical frameworks.

\section{References}

Anderson, L. M. \& Bird T. (1992) Transforming teachers' beliefs about teaching, learning and learners Michigan State University, National Center for Research on Teaching, East Lansing.

Ball, D. L. (1988a). Knowledge and reasoning in mathematics pedagogy: Examining what prospective teachers bring to teacher education. Doctoral dissertation, Michigan State University, East Lansing.

Ball, D. L. (1988b). Unlearning to teach mathematics. For the learning of mathematics, $8,1,40-48$.

Ball, D. L. (1990). Breaking with experience in learning to teach mathematics: the role of a preservice methods course. For the learning of Mathematics, 10, 2, 10-16.

Buchmann, M. \& Schwille, J. (1982). Education: the overcoming of experience. East Lansing, MI: Institute for Research on Teaching, Michigan State University

Bullough, R. V. (1997). Becoming a teacher: Self and social location of teacher education. In B. J. Biddle et al. (Eds.), International Handbook of Teachers and Teaching, pp.79-134. The Netherlands: Kluwer Academic Publishers.

Calderhead, J. (1991). The nature and growth of knowledge in student teaching. Teaching and Teacher Education, 7: 531-537.

Darling-Hammond, L. (1991). Are our teachers ready to teach? Quality Teaching, 1(1), 6-7, 10.

Darling-Hammond, L. (1999). Teacher quality and student achievement: A review of state policy evidence. Seattle: University of Washington, Center for Teaching and Policy.

Derry, S. J. and The STEP team (2002). The STEP System for Collaborative Case-Based Teacher Education: Design, Evaluation \& Future Directions. Proceedings of Computer Support for Collaborative Learning (CSCL). Mahwah, NJ: Earlbaum 2002.

Education Commission of the States (2003). Eight questions on teacher preparation: what does the research say? Report published by ECS Available on-line at http://www.ecs.org/tpreport

Fergoson, R. F. \& Womack, S. T. (1993). The impact of subject matter and education coursework on teaching performance. Journal of Education, 44: 155-163. 
Fieman-Nemser, S. \& Remillard, J. (1996) Prospectives on teaching and learning. Michigan State University. East Lansing

Fieman-Nemser, S., \& M. Buchmann (1986). The first year of teacher preparation: transition to pedagogical thinking. Journal of curriculum Studies, 18: 239-256.

Grossman, P. L. (1989). Learning to teach without teacher education. Teachers' College record, 91, 2, 191-207.

Lampert, M. \& Ball, D. L. (1990). Using Hypermedia Technology to Support a New Pedagogy of Teacher Education. East Lansing: The National Center for Research on Teacher Education, Michigan State University.

Masingila, J. O. \& Doerr, H. M. (2002). Understanding pre-service teachers' emerging practices through their analyses of a multimedia case study of practice. Journal of Mathematics Teacher Education, 5: 235-263.

Merseth, K. K. \& Lacey, C. A. (1993). Weaving stronger fabric: The pedagogical promise of hypermedia and case methods in teacher education. Teacher and Teacher Education, 9(3), 283-299.

Merseth, K. K. (1994). Cases, Case methods and the professional development of educators. ERIC Digest: ERIC Clearinghouse on Teaching and Teacher Education, Washington, DC.

Mousley, J. \& Sullivan, P. (1997) Dilemmas in the professional education of mathematics teachers. In E. Pekhonnen (ed), Proceedings of the $21^{\text {st }}$ Conference of the International Group for Psychology of Mathematics Education (pp. 131-147). Lahti, Finland: University of Helsinki, Lahti Research and Training Centre.

Putnam, R. T. \& Borko, H. (2000). What do new views of knowledge and thinking have to say about research on teacher learning? Educational Researcher, Online version 29(1), 4-15.

Shulman, L. (1987). Knowledge and teaching: Foundations of the new reforms. Harvard Educational Review, 57(1).

Sullivan, P. (2002).Editorial: Using the study of practice as a learning strategy within mathematics teacher education programs. Journal of Mathematics Teacher Education, 5, 289-292.

Thompson, A. G. (1984). The relationship of teachers' conceptions of mathematics and mathematics teaching to practice. Educational studies in Mathematics, 15, 105127. 